\title{
Meningkatkan Kinerja Guru dalam Menyusun Silabus dan Rencana Pelaksanaan Pembelajaran (RPP) melalui Supervisi Kolegial
}

\section{Made Darwis Wibawa*}

\author{
SMK Negeri 1 Sukasada
}

\author{
A R T I C L E I N F O \\ Article history: \\ Received 19 November \\ 2018 \\ Received in revised form \\ 30 December 2018 \\ Accepted 10 January 2019 \\ Available online 20 \\ February 2019 \\ Kata Kunci: \\ Supervisi Kolegial, Kinerja \\ Guru Dalam Menyusun \\ Silabus dan Rencana \\ Pelaksanaan \\ Pembelajaran (RPP) \\ Keywords: \\ Collegial supervision, \\ teacher performance in \\ compiling syllabus and \\ learning implementation \\ plan (RPP)
}

\begin{abstract}
A B S T R A K
Penelitian ini bertujuan meningkatkan kinerja guru dalam menyusun silabus dan rencana pelaksanaan pembelajaran (RPP) supervisi kolegial di SMK Negeri 1 Sukasada Tahun Pelajaran 2018/2019. Jenis penelitian ini adalah tergolong penelitian tindakan sekolah. Penelitian dilaksanakan sebanyak 3 siklus. Subyek penelitian adalah siswa seluruh guru yang tergolong guru tetap dan guru tidak tetap yang berjumlah 80 orang. Data dianalisis menggunakan statistik deskriptif. Berdasarkan hasil penelitian didapatkan Terjadi peningkatan kinerja guru setelah diberi pembinaan melalui supervisi kolegial yaitu dari $60,3 \%$ menjadi $64,6 \%$ ada kenaikan sebesar $=4,3 \%$ Dari sebelum pembinaan (siklus 1) dan setelah pembinaan oleh kepala sekolah sampai dengan (siklus 3) ; 60,3\% menjadi 64,6\%, dan dari (siklus 2) ke (siklus 3) juga ada peningkatan sebanyak $82,2 \%-64,6 \%=17,6 \%$. Ratarata peningkatan kinerja guru dalam penyusunan silabus dan rancangan pelaksanaan pembelajaran (RPP) sebelum diberi pembinaan naik dari $39,08 \%$ menjadi $100 \%$. Dari analisis data di atas bahwa pembinaan kepala sekolah melalui supervisi kolegial terbukti efektif diterapkan dalam meningkatkan kinerja guru melalui supervisi kolegial secara berkelanjutan.
\end{abstract}

\section{A B S T R A C T}

This study aims to improve teacher performance in preparing syllabus and plan for implementing learning (RPP) collegial supervision at SMK Negeri 1 Sukasada in the 2018/2019 Academic Year. This type of research is classified as school action research. The study was conducted in 3 cycles. The research subjects were students of all teachers belonging to permanent teachers and non-permanent teachers, amounting to 80 people. Data were analyzed using descriptive statistics. Based on the results of the study, there was an increase in teacher performance after being given coaching through collegial supervision, from $60.3 \%$ to $64.6 \%$, there was an increase of $=4.3 \%$ from before coaching (cycle 1) and after guidance by the principal up to (cycle 3); $60.3 \%$ to $64.6 \%$, and from (cycle 2) to (cycle 3) there was also an increase of $82.2 \%-64.6 \%=17.6 \%$. The average increase in teacher performance in the preparation of the syllabus and the design of the implementation of learning (RPP) before being given guidance increased from $39.08 \%$ to $100 \%$. From the data analysis above, the guidance of principals through collegial supervision has proven to be effective in improving teacher performance through ongoing collegial supervision. 


\section{Pendahuluan}

Dalam upaya mencapai tujuan tersebut di atas, Guru memiliki peranan yang sangat penting. Kedudukan Guru dan Dosen sebagai tenaga professional bertujuan untuk melaksanakan system pendidikan nasional dan mewujudkan tujuan pendidikan nasional .

Berdasarkan Undang-undang Republik Indonesia No. 14 Tahun 2005 tentang Guru dan Dosen Pasal 10, dinyatakan bahwa kompetensi guru meliputi kompetensi paedagogik, kompetensi kepribadian, kompoetensi sosial, dan kompetensi profesional yang diperoleh melalui pendidikan profesi.

Dalam penjelasannya yang dimaksud kompetensi pedagogik adalah kemampuan guru mengelola pembelajaran peserta didik, kompetensi kepribadian adalah kemampuan kepriadian yang mantap, berakhlak mulia, arif, dan berwibawa serta menjadi teladan peserta lain; yang dimaksud kompetensi profesional adalah kemampuan guru dalam penguasaan materi pelajaran secara luas dan mendalam dan yang dimaksud dengan kompetensi soaial adalah kemampuan guru untuk berkomunikasi dan berinteraksi secara efektif dan efisien dengan peserta didik, sesama guru, orang tua/wali peserta didik dan masyarakat sekitar.

Sebagai acuan dasar kendali mutu pendidikan di semua jenjang diseluruh wilayah Negara Kesatuan Republik Indonesia, pemerintah telah Peraturan Menteri Pendidikan Nasional No. 19 Tahun 2005 tentang Standar Nasional Pendidikan (SNP). Standar Nasional Pendidikan (SNP) adalah kriteria minimal tentang sistem pendidikan di seluruh wilayah hukum Negara Kesatuan Republik Indonesia. Lingkup Standar Nasional Pendidikan meliputi: 1) standar isi adalah ruang lingkup materi dan tingkat kompetensi yang dituangkan dalam kriteria tentang kompetensi tamatan, kompetensi bahan kajian, kompetensi mata pelajaran, dan silabus pembelajaran yang harus dipenuhi oleh peserta didik pada jenjang dan jenis pendidikan tertentu. 2) standar proses adalah standar nasional pendidikan yang berkaitan dengan pelaksanaan pembelajaran pada satu satuan pendidikan untuk mencapai standar kompetensi lulusan. 3) standar kompetensi lulusan adalah kualifikasi kemampuan lulusan yang mencakup sikap, pengetahuan, dan keterampilan 4) standar pendidik dan tenaga kependidikan adalah kriteria pendidikan prajabatan dan kelayakan fisik maupun mental, serta pendidikan dalam jabatan. 5) standar sarana dan prasarana adalah standar nasional pendidikan yang berkaitan dengan kriteria minimal tentang ruang belajar, tempat berolahraga, tempat beribadah, perpustakaan, laboratorium, bengkel kerja, tempat bermain, tempat berkreasi dan berekreasi, serta sumber belajar lain, yang diperlukan untuk menunjang proses pembelajaran, termasuk penggunaan teknologi informasi dan komunikasi. 6) standar pengelolaan adalah standar nasional pendidikan yang berkaitan dengan perencanaan, pelaksanaan, dan pengawasan kegiatan pendidikan pada tingkat satuan pendidikan, kabupaten/Kabupaten, provinsi, atau nasional agar tercapai efisiensi dan efektivitas penyelenggaraan pendidikan. 7) standar pembiayaan adalah standar yang mengatur komponen dan besarnya biaya operasi satuan pendidikan yang berlaku selama satu tahun; dan 8) standar penilaian pendidikan adalah standar nasional pendidikan yang berkaitan dengan mekanisme, prosedur, dan instrumen penilaian hasil belajar.

Dari 8 Standar Nasional Pendidikan di atas yang sangat erat hubungannya dengan tugas guru dan kepala sekolah adalah Standar Proses. Yaitu standar yang berhungan langsung dengan proses pembelajaran di setiap satuan pendiidikan. Peraturan Menteri Pendidikan Nomer 41 Tahun 2007 tentang Standar Proses. Standar proses mencakup tentang: 1) Perencanaan proses pembelajaran, 2) Pelaksanaan proses pembelajaran, 3) Penilaian hasil pembelajaran, dan 4) Pengawasan proses pembelajaran. Perencanaan proses pembelajaran berupa Silabus dan Rencana Pelaksanaan Pembelajaran (RPP). Pengawasan Proses Pembelajaran dilakukakan oleh Guru dan kepala Sekolah melalui Pemantauan, Supervisi, Evaluasi, Pelaporan dan Tindak Lanjut.

Kenyataan yang terjadi di lapangan, bahwa berdasarkan hasil pemantauan kepala sekolah sejak menjabat menjadi kepala sekolah masih banyak guru di SMK Negeri 1 Sukasada di Kabupaten Buleleng yang belum mampu menyusun Silabus dan RPP dengan benar. Rata-rata kemampuan guru pada tahun 2018 masih diperoleh 40\% guru belum kompeten pada aspek perencanaan pembelajaran. Kelemahan guru dalam menyusun RPP khususnya masih banyak terlihat pada ketidak sesuaian antara standar kompetensi, kompetensi dasar (SK/KD) dan Indikator, ketidak sesuaian antara materi dan metoda pembelajaran yang digunakan, ketidaksesuaian antara kegiatan pembelajaran dan dengan langkahlangkah pemebelajaran dan lain-lain. Hal inilah yang menyebabkan guru tidak dapat melaksanakan perencanaannya dengan baik pada proses pembelajaran di kelas.

Atas dasar permasalahan di atas maka perlu dicari solusinya agar bagaimana guru-guru di SMK Negeri 1 Sukasada di Kabupaten Buleleng ini dapat meningkatkan kemampuannya dalam menyusun perencanaan pembelajaran dengan baik dan benar. Banyak cara yang dapat dilakukan kepala sekolah dalam rangka melakukan pembinaan kepada guru dalam rangka meningkatkan mutu pembelajaran di sekolah. Supervisi Kolegial adalah salah satu teknik supervisi yang menekankan hubungan baik yang 
saling membutuhkan berdasarkan perbedaan kemampuan, kebutuhan, dan kemitraan (kolega) yang bersifat pendampingan kooperatif dan timbal balik. Dengan tehnik supervisi kolegial ini akan dapat membantu guru dengan lebih cepat dan efisien untuk meningkatkan kemampuannya menyusun rencana pembelajaran. Untuk mengetahui efektifitas pelaksanaan supervisi kolegial secara ilmiah, maka perlu dilakukan penelitian tindakan sekolah (PTS) dengan judul : "Peningkatan Kinerja Guru Dalam Menyusun Silabus dan Rencana Pelaksanaan Pembelajaran (RPP) melalui Supervisi Kolegial di SMK Negeri 1 Sukasada di Kabupaten Buleleng Tahun pelajaran 2018/2019".

Istilah kemampuan mengajar guru merupakan kemampuan guru dalam menigkatkan kinerjanya melaksanakan pembelajaran di kelas. Kinerja dapat diterjemahkan dalam perfomance atau unjuk kerja, artinya kemampuan yang ditampilkan seseorang terhadap pekerjaannya pada tempat ia bekerja. Kinerja merupakan suatu kinerja yang esensial terhadap keberhasilan suatu pekerjaan (Murwati,2013). Karena itu suatu kinerja yang efektif bagi setiap individu perlu diciptakan sehingga tujuan lembaga dapat tercapai secara optimal (Agustina, 2006). Menurut Fattah (1996) kinerja diartikan sebagai ungkapan kemajuan yang didasari oleh pengetahuan, sikap, keterampilan dan otivasi dalam menghasilkan suatu pekerjaan. Dengan demikian dapat disimpulkan bahwa kinerja adalah hasil kerja seseorang yang mencerminkan prestasi kerja sebagai ungkapan pengetahuan, sikap dan keterampilan.

Menurut Supriadi (1998) kinerja guru akan menjadi lebih baik, bila seorang guru memiliki lima hal yakni: 1.Mempunyai komitmen pada siswa dan proses belajarnya, 2. Menguasai secara mendalam bahan mata pelajaran yang akan diajarkan serta cara mengajarnya kepada siswa, 3. Bertanggung jawab memantau hasil belajar siswa melalui berbagai cara evaluasi dan, 4. Guru mampu berpikir sistematis tentang apa yang dilakukannya dan belajar serta pengalamannya.

Lebih lanjut Hamalik (2002) kemampuan dasar yang disebut juga kinerja dari seorang guru teridiri dari: (1) kemampuan merencanakan pembelajaran, (2) kemampuan mengelola program belajar mengajar, (3) kemampuan menglola kelas (4) kemampuan menggunakan media/sumber belajar, (5) kemampuan menglola interaksi belajar mengajar, (6) mampu melaksanakan evaluasi belajar siswa. Kinerja guru sangat terkait dengan efektifitas guru dalam melaksanakan fungsinya oleh Medley dalam Depdikbud (1984) dijelaskan bahwa efektifitas guru yaitu: (1) memiliki pribadi kooperatif, daya tarik, penampilan amat besar, pertimbangan dan kepemimpinan, (2) menguasai metode mengajar yang baik, (3) memiliki tingkah laku yang baik saat mengajar, dan (4) menguasai berbagai kompetensi dalam mengajar. Evaluasi kinerja guru mutlak dilakukan, karena masih terdapat banyak kinerja guru yang kurang memadai, di samping itu guru dituntut dapat mengikuti perkembangan ilmu pengetahuan, teknologi dan seni yang terus berkembang pula dengan pesat. Istilah kinerja berasal dari bahasa inggris yaitu Performance, berarti hasil kena atau unjuk kerja yang dicapai seseorang atau sekelompok orang/organisasi tertentu. Istilah kinerja dapat diterjemahkan dalam unjuk kerja, artinya kemampuan yang ditampilkan seseorang terhadap pekerjaannya di tempat ia bekerja. Kinerja merupakan suatu hal yang sangat esensial terhadap keberhasilan suatu pekerjan. Pada hakikatnya orang bekerja untuk memenuhi kebutuhan atas dorongan tertentu. Kebutuhan dipandang sebagai penggerak atau pembangkit perilaku, sedangkan tujuannya berfungsi untuk menggerakkan perilaku. Karena itu suatu kinerja yang efektif bagi setiap individu, perlu disiptakan sehingga tujuan lembaga dapat tercapai secara optimal.

Penelitian ini bertujuan untuk meningkatkan kemampuan profesional guru dalam meningkatkan proses dan hasil belajar melalui pemberian bantuan yang terutama bercorak layanan profesional kepada guru

\section{Metode}

Subyek dalam penelitian ini adalah peningkatan kinerja guru dalam menyusun silabus dan Rencana Pelaksanaan Pembelajaran (RPP). Berdasarkan hasil observasi yang penulis lakukan bahwa kinerja guru di SMK Negeri 1 Sukasada dalam menyusun silabus dan RPP masih sangat rendah. Guru merasa kesulitan dalam menyusun silabus dan RPP akibatnya guru kurang respon terhadap pembinaan yang dilakukan kepala sekolah. Penelitian ini merupakan penelitian tindakan sekolah, yang dilakukan secara bertahaptahap sampai mendapatkan hasil yang diinginkan. Rancangan Penelitian Tindakan Sekolah (PTS) menurut Kemmis dan Mc.Taggar (Depdiknas,2000) adalah seperti gambar berikut: 


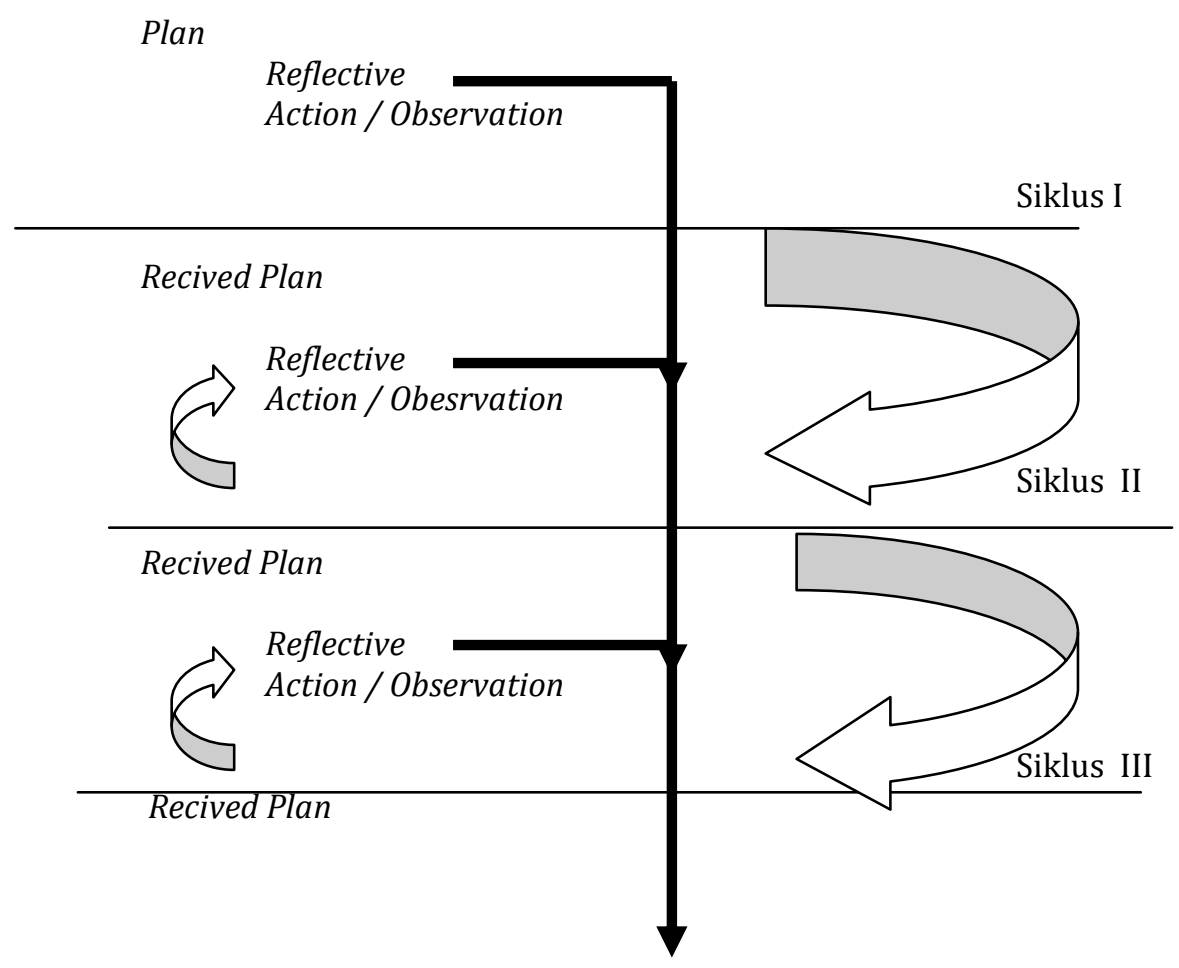

Gambar 3.1. Alur Penelitian Tindakan Sekolah

Penelitian tindakan sekolah (PTS) yang dilaksanakan dalam tiga siklus dianggap sudah berhasil apabila terjadi peningkatan kinerja guru dalam menyusun silabus dan merancang RPP mencapai 80\% guru (sekolah yang diteliti) telah mencapai ketuntasan dengan nilai rata rata 75. Jika peningkatan tersebut dapat dicapai pada tahap siklus 1 dan 2, maka siklus selanjutnya tidak akan dilaksanakan karena tindakan sekolah yang dilakukan sudah dinilai efektif sesuai dengan harapan dalam manajemen berbasis sekolah (MBS).

Dalam analisis data teknik yang digunakan adalah ; 1) Kuantitati: Analisis ini digunakan untuk menghitung besarnya peningkatan kinerja guru melalui supervisi kolegial oleh kepala sekolah dengan menggunakan prosentase (\%), 2) Kualitatif: Teknik analisis ini digunakan untuk memberikan gambaran hasil penelitian secara ; reduksi data, sajian deskriptif, dan penarikan simpulan.

\section{Hasil dan Pembahasan}

1. Ketuntasan Hasil Pembinaan Kepala Sekolah

Melalui hasil peneilitian ini menunjukkan bahwa pembinaan melalui supervisi kolegial memiliki dampak positif dalam meningkatkan kinerja guru dalam menyusun silabus dan merancang RPP, hal ini dapat dilihat dari semakin mantapnya pemahaman guru terhadap pembinaan yang disampaikan kepala sekolah (kinerja guru dari siklus I, II, dan III) yaitu masing-masing 60,3\%;64,6\%;82,2\% Pada siklus III guru secara kelompok dikatakan tuntas.

2. Kemampuan Kepala Sekolah dalam meningkatkan Kinerja guru ;

Berdasarkan analisis data, diperoleh aktivitas guru dalam meningkatkan kinerjanya pada setiap siklus mengalami peningkatan. Hal ini berdampak positif terhadap capaian mutu sekolah yaitu dapat ditunjukkan dengan meningkatnya nilai rata-rata guru pada setiap siklus yang terus mengalami peningkatan.

3. Aktivitas Kepala Sekolah dan Guru dalam meningkatkan kinerja

Berdasarkan analisis data, diperoleh aktivitas guru, kepala sekolah yang paling dominan dalam kegiatan pembinaan adalah bekerja dengan menggunakan alat/media, mendengarkan/memperhatikan penjelasan kepala sekolah, dan diskusi antar guru dalam meningkatkan kinerja guru. Jadi dapat dikatakan bahwa aktivitas guru dapat dikategorikan aktif.

Sedangkan untuk aktivitas kepala sekolah selama pembinaan telah melaksanakan langkah-langkah pembinaan melalui supervisi kolegial dengan baik. Hal ini terlihat dari aktivitas guru yang muncul 
diantaranya aktivitas membuat dan merencanakan program pembelajaran, melaksanakan, memberi umpan balik/evaluasi/tanya jawab di mana prosentase untuk aktivitas di atas cukup besar.

Berdasarkan hasil penelitian di atas, peningkatan kinerja guru dalam menyusun silabus dan merancang RPP di SMK Negeri 1 Sukasada hasilnya sangat baik. Hal itu tampak pada siklus pertama dari 80 orang guru yang ada pada saat penelitian ini dilakukan nilai rata-rata mencapai ; 60,3\% meningkat menjadi $64,6 \%$ dan pada siklus 3 meningkat menjadi $82,2 \%$.

Dari analisis data di atas bahwa pembinaan kepala sekolah melalui supervisi kolegial efektif diterapkan dalam meningkatkan kinerja guru yang berarti proses pembinaan kepala sekolah lebih berhasil dan dapat meningkatkan capaian mutu sekolah khususnya di SMK Negeri 1 Sukasada, oleh karena itu diharapkan kepada para kepala sekolah dapat melaksanakan pembinaan melalui supervisi kolegial secara berkelanjutan.

Berdasarkan analisis data di atas, maka kinerja guru dalam menyusun silabus dan merancang RPP, ke arah perubahan yang diinginkan mencapai $80 \%$ ketercapaiannya, maka kinerja guru tersebut dikatakan meningkat dan efektif dalam meningkatkan capaian mutu sekolah di SMK Negeri 1 Sukasada. Dengan demikian maka hipotesis yang diajukan di atas dapat diterima.

\section{Simpulan dan Saran}

Berdasarkan hasil penelitian di atas, peningkatan kinerja guru dalam menyusun silabus dan merancang RPP di SMK Negeri 1 Sukasada hasilnya sangat baik. Hal itu tampak pada siklus pertama dari 80 orang guru yang ada pada saat penelitian ini dilakukan nilai rata-rata mencapai ; 60,3\% meningkat menjadi $64,6 \%$ dan pada siklus 3 meningkat menjadi $82,2 \%$. Dengan demikian maka hipotesis yang diajukan di atas dapat diterima.

Berdasarkan simpulan di atas, dapat disampaikan beberapa saran yaitu: 1. Bagi guru, (a) Alokasi waktu diatur sebaik mungkin sehingga tiap tahapan pembelajaran dapat berlangsung secara optimal; (b) Pembagian kelompok harus benar-benar diperhatikan yakni secara heterogen berdasarkan jenis kelamin dan prestasi siswa; (c) Memberikan bimbingan individu dan kelompok secara merata; (d) Memahami sifat dan karakteristik anak, 2. Bagi siswa, siswa diharapkan berperan aktif dalam pembelajaran, memperhatikan penjelasan guru dan ikut terlibat dalam setiap kegiatan pembelajaran sehingga prestasi belajar akan meningkat serta diharapkan dapat berkerja secara mandiri maupun kelompok dan bertanggungjawab atas tugas yang diberikandan 3. Bagi Kepala Sekolah, diharapkan mengembangkan dan mengkaji lebih luas lagi model-model pembelajaran untuk mendukung proses belajar mengajar yang sesuai dengan kurikulum dan karakteristik anak meliputi sarana dan prasarana yang menunjang pembelajaran

\section{Daftar Rujukan}

Agustina, H. and INDRAWATI YULIANI, I., 2006. Faktor-faktor yang mempengaruhi kinerja guru matematika dalam pelaksanaan kurikulum berbasis kompetensi (kbk) pada sekolah menengah atas Kota Palembang. Jurnal Bisnis dan Manajemen, 4(7), pp.24-31.

Arifin, I. 2000. Profesionalisme Guru: Analisis Wacana Reformsi Pendidikan dam Era Globalisasi. Simposium Nasional Pendidikan di Universitas Muhammadiyah Malang, 25-26 Juli 2001.

Anom. 2009. Materi Training of the Trainers (TOT) Calon Pengawas Sekolah, Kompetensi Evaluasi Pendidikan. Jakarta: Direktorat Tenaga Kependidikan.

Arikunto, Suharsini. 2004. Dasar - dasar Supervisi. Jakarta: Rineka Cipta.

Arikunto, Suharsini. 2007. Penelitian Tindakan Kelas.Jakarta: PT.Bumi Aksara.

Atmodiwiro, Soebagio dan Soenarto Tatosiswanto, 1991. Kepemimpinan Kepala Sekolah, Semarang: Adhi Waskitho.

Dirjen PMPTK,2009.BBM Kelompok Kerja kepala sekolah dimensi kmpetensi evaluasi.Jakarta : PMPTK Depdiknas.

Djaali. 2008. Pengukuran Dalam Bidang Pendidikan. Jakarta: PPs Universitas Negeri Jakarta. 
Djatmiko, E., 2006. Pengaruh kepemimpinan kepala sekolah dan sarana prasarana terhadap kinerja guru smp negeri kota semarang. Fokus Ekonomi: Jurnal Ilmiah Ekonomi, 1(2).

Hidayat, Z., 2016. Pengaruh Stres Dan Kelelahan Kerja Terhadap Kinerja Guru SMPN 2 Sukodono Di Kabupaten Lumajang. Wiga: Jurnal Penelitian Ilmu Ekonomi, 6(1), pp.36-44.

Murwati, H., 2013. Pengaruh sertifikasi profesi guru terhadap motivasi kerja dan kinerja guru di smk negeri se-Surakarta. Jurnal Pendidikan Bisnis dan Ekonomi (BISE), 1(1), pp.1-10.

Peraturan No 12 Tentang Kompetensi Pengawas. 2007. Jakarta: Departemen Pendidikan Nasional.

Peraturan Menteri No 13 Tentang Kompetensi Kepala Sekolah. Jakarta: Departemen Pendidikan Nasional.

Peraturan Menteri No 19 Tentang Standar Pengelolaan Sekolah/Madrasah. Jakarta : Departemen Pendidikan Nasional.

Peraturan Menteri Pendidikan Nasional Republik Indonesia Nomor 20 Tahun 2007 tentang Standar Penilaian Pendidikan. Jakarta: Badan Standar Nasional Pendidikan.

Setiyati, S., 2014. Pengaruh kepemimpinan kepala sekolah, motivasi Kerja, dan budaya sekolah terhadap kinerja guru. Jurnal Pendidikan Teknologi dan Kejuruan, 22(2), pp.200-206.

Wardana, D.S., 2013. Motivasi berprestasi dengan kinerja guru yang sudah disertifikasi. Jurnal Ilmiah Psikologi Terapan, 1(1), pp.98-109.

Wulan, S., 2013. Hubungan disiplin dengan kinerja guru SMA Negeri di tiga kecamatan Kota Depok. Jurnal Ilmiah Widya, 1(2), pp.106-112. 